\title{
Intensive Care Unit Admission Parameters for Patients with COVID-19
}

\section{COVID-19 Hastalarında Yoğun Bakım Kabulünü Belirleyen Parametreler}

\author{
(D) Mehmet Süleyman Sabaz¹, (D) Fatma Özdemir², (D) Oğuz Özakin², (1) Ülkü Aygen Türkmen², (D) Veysel Dinç² \\ ${ }^{1}$ Marmara University Pendik Training and Research Hospital, Clinic of Anesthesiology and Reanimation, Division of Intensive Care, İstanbul, Turkey \\ 2University of Health Sciences Turkey, Gaziosmanpaşa Training and Research Hospital, Clinic of Anesthesiology and Reanimation, İstanbul, Turkey
}

\begin{abstract}
Objective: The aim of this study was to determine the factors that may be useful in the early identification of populations that are sensitive to Coronavirus disease-2019 (COVID-19) and the need for intensive care unit (ICU) admission.

Methods: In this retrospective cohort study, patients who were hospitalized with COVID-19 and requested intensive care consultation at University of Health Sciences Turkey, Gaziosmanpaşa Training and Research Hospital between April 1 and July 1, 2020 were analyzed.

Results: Of the 208 patients included in the study, 129 were admitted to the ICU and 79 were not. Patients over the age of 85 were more often admitted to the ICU. The probability of ICU admission increased 2.6 times [odds ratio (OR): 2.687; confidence interval (CI): 95\% 1.172-6.164] in patients with a single comorbidity relative to those with no comorbidity, while this risk increased 9.8 times (OR: 9.825, Cl: 95\% 2.557-37.749) in the presence of four or more comorbidities. In patients admitted to the ICU, the D-dimer and ferritin levels were higher, and the lymphocyte count was lower $(p<0.001)$, relative to those who were not. Receiver operator characteristic $(R O C)$ analysis gave cut-off values of $520 \mathrm{ng} / \mathrm{mL}$, 765 $\mathrm{ng} / \mathrm{mL}$, and $0.89109 / \mathrm{L}$ for ferritin, D-dimer and the lymphocyte count.

Conclusion: In addition to male gender and advanced age, a higher number of comorbidities is associated with higher disease severity in patients with COVID-19. It is also believed that a low lymphocyte count, as well as high D-dimer and ferritin levels, may guide clinicians in the early diagnosis of patients who require ICU admission.
\end{abstract}

Keywords: COVID-19, SARS-CoV-2, coronavirus, intensive care units, admission parameters

\section{öz}

Amaç: Bu çalışma, Koronavirüs hastalığı-2019 (COVID-19) hastalarında yoğun bakım ünitesine (YBÜ) kabul parametrelerinin belirlenmesi amacı ile planlanmıştır.

Gereç ve Yöntem: Retrospektif tasarıma sahip bu araştırmada 1 Nisan-1 Temmuz 2020 tarihleri arasında Sağlık Bilimleri Üniversitesi, Gaziosmanpaşa Eğitim ve Araştırma Hastanesi'nde COVID-19 tanısı ile hastaneye yatırılan ve yoğun bakım konsültasyonu talep edilen hastalar analiz edildi.

Bulgular: Araştırmaya dahil edilen 208 hastanın 129'u YBÜ'ye kabul edildi 79'unda ise YBÜ'ye gerek görülmedi. Seksen beş yaş üzeri hastaların YBÜ kabulünün daha fazla olması dışında gruplar arasında ortalama yaş benzer bulundu. Komorbiditesi olmayan hastalara göre tek bir komorbiditesi olanlarda YBÜ olasılığı 2,6 kat artarken, bu riskin 4 ve üzeri komorbidite varlığında 9,8 kat arttığı bulundu. YBÜ’ye kabul edilen hastalarda D-dimer ve ferritin değerleri daha yüksek, lenfosit sayısı daha düşük bulundu $(p<0,001)$. Ferritin değeri için yapılan ROC analizi sonucunda cut-off değeri $520 \mathrm{ng} / \mathrm{ml}$ olarak, D-dimer değeri için cut-off değeri $765 \mathrm{ng} / \mathrm{mL}$ olarak, lenfosit sayısı için cut-off değeri 0,89 109/L olarak belirlendi

Sonuç: COVID-19 hastalarında erkek cinsiyet ve ileri yaşa ek olarak daha fazla sayıda komorbidite, daha yüksek hastalık şiddeti ile ilişkilidir. Ayrıca lenfosit sayısı düşüklüğü, D-dimer ve ferritin yüksekliğinin YBÜ kabulü gerekecek hastaların erken tanınmasında klinisyenlere yol gösterebileceği düşünülmektedir.

Anahtar Kelimeler: COVID-19, SARS-CoV-2, coronavirus, yoğun bakım üniteleri, kabul parametreleri

Address for Correspondence: Mehmet Süleyman Sabaz, Marmara University Pendik Training and Research Hospital, Clinic of Anesthesiology and Reanimation, Division of Intensive Care, İstanbul, Turkey

Phone: +90 5064415710 E-mail: udmss_47@hotmail.com ORCID ID: orcid.org/0000-0001-7034-0391

Cite as: Sabaz MS, Özdemir F, Özakin O, Türkmen ÜA, Dinç V. Intensive Care Unit Admission Parameters for Patients with COVID-19

Med J Bakirkoy 2021;17:254-261

Received: 03.09.2021

Accepted: 17.09.2021 


\section{INTRODUCTION}

In December 2019, a disease was reported in the Wuhan State of China caused by Severe Acute Respiratory syndrome-Coronavirus-2 (SARS-CoV-2) (1). The World Health Organization declared a pandemic due to this infectious disease, which was designated Coronavirus disease-2019 (COVID-19) and it had caused more than 225 million cases and 4,636,153 deaths in 220 countries as of September 14, $2021(2,3)$. It is expected that this number will continue to increase rapidly for a while and will threaten the lives of more people worldwide, as well as their physical and mental health.

The first investigations of COVID-19 revealed a clinical spectrum ranging from moderate infection to severe complications such as acute respiratory distress syndrome and multiple organ dysfunction syndrome, which resulted in death, following an incubation period of 2 to 14 days $(4,5)$. To date, no specific treatment has been proven for this disease other than supportive care. Recent reports have indicated that approximately $14 \%-29 \%$ of patients with COVID-19 pneumonia required intensive care (IC) $(6,7)$. In this pandemic, which is predicted to cause great pressure and insufficiency in intensive care units (ICUs), early recognition of critical patients and ensuring timely triage is very important (8). Reports from China and Italy demonstrated that the risk factors for severe disease included advanced age and at least one comorbid disease $(4,9)$. Particularly, elderly patients who have underlying comorbidities such as diabetes, hypertension, and coronary heart disease are at greater risk of adverse outcomes (10).

The requirement for ICU admission is primarily determined by the clinical view, peripheral oxygen saturation $\left(\mathrm{SpO}_{2}\right)$ levels, and the patient's comorbidities, although specific laboratory markers may aid in determining the severity of the condition. In order to predict the need for ICU admission in hospitalized COVID-19 patients, it is recommended to consider the levels of $\mathrm{C}$-reactive protein (CRP), D-dimer level, ferritin, and serum cardiac troponin, as well as the low lymphocyte count (11). This study was planned to determine the parameters that may be useful in predicting the ICU need of COVID-19 and to identify the factors affecting the progression from mild to severe disease.

\section{METHODS}

\section{Subjects and Methods}

This retrospective cohort study was conducted at the ICU of University of Health Sciences Turkey, Gaziosmanpaşa
Training and Research Hospital, İstanbul, Turkey. This referral hospital, which has 600 beds and 40 different medical departments, includes an ICU consisting of 38 patient beds admitting an average of 3.386 medical, surgical, or trauma patients per year. The ratio of nurses to patients is 1:2 in this unit, which provides IC services as a separate unit, where extracorporeal treatments (ECMO, hemodialysis, plasmapheresis) can be administered $24 / 7$ by the IC specialists, Anesthesiology and Reanimation specialists, and assistants.

\section{Data Collection}

The data on patients who were hospitalized for COVID-19 in our hospital between April 1 and July 1,2020 and were consulted for assessment of the need for ICU admission, were collected using the hospital database. Treatment for COVID-19 was planned according to the guidelines published and updated by the Ministry of Health $(12,13)$. The findings of respiratory rate $\geq 30$ times/min, dyspnea and respiratory distress symptoms, $\mathrm{SaO}_{2}$ (arterial oxygen saturation) $<90 \%$ or $\mathrm{PaO}_{2}$ (partial pressure of oxygen) 70 $\mathrm{mmHg}$ despite oxygen support, $\mathrm{PaO} 2 / \mathrm{FiO}_{2}$ (the fraction of inspired oxygen) $300,4 \mathrm{mmol} / \mathrm{L}$ lactate, bilateral infiltrates or multilobar involvement, on chest X-ray or computed tomography, hypotension (mean arterial pressure $65 \mathrm{mmHg}$ ), skin perfusion disorder, kidney or liver function disorder, thrombocytopenia, organ dysfunctions such as confusion, presence of immunosuppressive disease, the presence of multiple and particularly uncontrolled comorbidity, troponin elevation, and arrhythmia were evaluated as the indications for ICU admission (12).

The patients consultation responses were checked for the decision on follow-up in the ICU. Clinical and laboratory data of these patients during consultation were obtained electronically and evaluated retrospectively. Patient data including age, gender, comorbid diseases, respiratory rate per minute, $\mathrm{FiO}_{2}, \mathrm{SaO}_{2^{\prime}}$ laboratory parameters obtained from blood samples, and the data obtained as a result of examination and recorded on the hospital database consultation form were analyzed.

\section{Sample}

All the patients who were hospitalized with COVID-19 and were consulted for assessment of the requirement for ICU admission during the planning period of the study constituted the intended sample. During the study period, 23,269 outpatients presented to our hospital with a prediagnosis of COVID-19. A total of 1554 patients with a confirmed diagnosis of COVID-19 were hospitalized. ICU consultation was requested for 396 of these patients, and 
212 patients were admitted to the ICU. Following evaluation of the exclusion criteria, a total of 208 patients consulted to the ICU were included in the study.

\section{Inclusion Criteria}

It was planned to include all patients over the age of 18 who were followed up at the hospital with a diagnosis of COVID-19 and consulted to evaluate the need for ICU admission.

\section{Exclusion Criteria}

Younger than 18 years old $(n=1)$

Patients with multiple requests for consultation in the ICU $(n=62)$

Patients referred to an external center $(n=81)$

Patients referred from an external center $(n=31)$

Missing data $(n=15)$

\section{Ethical Considerations}

Ethical approval and institutional permission was obtained from the University of Health Sciences Turkey, Gaziosmanpaşa Training and Research Hospital Ethics Committee (decision number: 134, date: 05/08/2020). The Council for Scientific Research Studies of the Directorate General of Health Services, which is associated with the Ministry of Health of the Republic of Turkey, also gave permission. The research conforms to the provisions of the Declaration of Helsinki in 1995 (as revised in Brazil 2013).

\section{Statistical Analysis}

The data collected in the study were evaluated using SPSS Statistics, version 22.00 (IBM Corp.; Armonk, NY). The Shapiro-Wilk test was performed to determine if the data had a normal distribution. Numerical variables were reported as mean standard deviation or median and interquartile range (IQR) whereas categorical variables were given as frequency ( $n$ ) and percentage (\%) IQR. For numerical data comparisons, the independent samples t-test was employed, and the Mann-Whitney $U$ test was utilized when the assumptions of this test could not be met. For categorical variables, the chi-square test was employed, and when the chi-square test criteria were not satisfied, Fisher's Exact test was used. In addition, a logistic regression model including all the patients was created in order to determine the effect of the comorbid disease burden on ICU admission. Receiver operator characteristic (ROC) analysis was used to determine cut-off values for the laboratory parameters that were assumed to be predictive of ICU admission. A p-value less than 0.05 was identified as the level of statistical significance.

\section{Primary Outcome}

The primary aim of the study was to determine the parameters for admission to the ICU in patients who were followed-up due to COVID-19.

\section{Secondary Outcome}

The secondary aim of the study was to compare the patients' comorbidities and laboratory values and to determine the cut-off values that could determine the transition from mild to severe disease as well as the need for ICU admission.

\section{Results}

The patients' demographics and baseline characteristics are shown in Table 1. Patients who were consulted for ICU follow-up were split into two groups: those who had been admitted to the ICU and those who had not. The mean age was similar among the groups, and the number of patients over the age of 85 who were admitted to the ICU was higher. Male gender $(87 ; 69 \%, p<0.05)$ and comorbid diseases (111; $85.4 \%, p<0.05)$ were more common in patients who were admitted to the ICU. The number of comorbid diseases was higher in the group of patients who were admitted to the ICU [2 (1-3), p<0.001]. Hypertension was the most common comorbid disease in both groups. Diabetes mellitus (DM) (65; 50.4\%), cardiovascular disease (CVD) (37; 28.7\%), and chronic obstructive pulmonary disease (COPD) $(25,19.4 \%)$ were more common in the patients who were admitted to the ICU $(p<0.05)$.

Measurements of fever were found to be similar in all patients during the examination. Dyspnea was found in $91.5 \%$ (118) and tachypnea (respiratory rate $\geq 30$ per $\mathrm{min}$ ) in $85.7 \%$ (108) $(p<0.05)$ of the patients who were admitted to the ICU. Although patients admitted to the ICU were treated with $5 \mathrm{~L} / \mathrm{min} \mathrm{O}_{2}, \mathrm{SaO}_{2}$ was $<90 \%$ or $\mathrm{PaO}_{2}$ was $<70, \mathrm{PaO}_{2} / \mathrm{FiO}_{2}$ was $<300$, and the rate of circulatory disorders was higher $(p<0.05)$. The proportion of patients with hypotension (MAP $<65 \mathrm{mmHg}$ ), organ dysfunction symptoms, lactate $>4 \mathrm{mmol} / \mathrm{L}$, and bilateral or multilobar lung involvement on computed tomography scan were similar between the groups (Table 1).

Considering the laboratory parameters, $\mathrm{PaO}_{2}$ and $\mathrm{SaO}_{2}$ were lower in the blood gasses of the patients who were admitted to the ICU. The D-dimer and ferritin levels were higher, and the lymphocyte counts were lower in patients who were admitted to the ICU (Table 2).

A logistic regression model was created to assess the effect of the comorbidity burden on ICU admission. As a result of this model, the ICU admission risk was 2.6 times higher in patients with one comorbid disease (odds ratio 


\begin{tabular}{|c|c|c|c|}
\hline Parameters & $\begin{array}{l}\text { Non-admission } \\
\text { to ICU }(n=79) \\
n(\%)\end{array}$ & $\begin{array}{l}\text { Admission to } \\
\text { ICU }(n=129) \\
n(\%)\end{array}$ & $p$ \\
\hline Gender & & & 0.010 \\
\hline Male & $39(31.0)$ & $87(69.0)$ & - \\
\hline Female & $40(48.8)$ & $42(51.2)$ & - \\
\hline $\begin{array}{l}\text { Age } \\
\text { (years, mean } \pm \text { SD) }\end{array}$ & $64.77 \pm 12.96$ & $67.85 \pm 14.86$ & 0.118 \\
\hline$<55$ & $18(22.8)$ & $24(18.6)$ & 0.466 \\
\hline $55-64$ & $19(24.1)$ & $29(22.5)$ & 0.794 \\
\hline $65-74$ & $18(22.8)$ & $27(20.9)$ & 0.753 \\
\hline $75-84$ & $21(26.6)$ & $28(21.7)$ & 0.421 \\
\hline$\geq 85$ & $3(3.8)$ & $21(16.3)$ & 0.006 \\
\hline Comorbidity & $54(69.2)$ & $111(85.4)$ & 0.005 \\
\hline Hypertension & $34(43.6)$ & $67(52.3)$ & 0.223 \\
\hline Diabetes & $23(29.1)$ & $65(50.4)$ & 0.003 \\
\hline $\begin{array}{l}\text { Cardiovascular } \\
\text { disease }\end{array}$ & $10(12.7)$ & $37(28.7)$ & 0.007 \\
\hline $\begin{array}{l}\text { Chronic obstructive } \\
\text { pulmonary disease }\end{array}$ & $5(6.3)$ & $25(19.4)$ & 0.009 \\
\hline $\begin{array}{l}\text { Cerebrovascular } \\
\text { disease }\end{array}$ & $7(8.9)$ & $24(18.6)$ & 0.055 \\
\hline Chronic renal failure & $11(13.9)$ & $24(18.6)$ & 0.381 \\
\hline Dementia & $6(7.6)$ & $11(8.5)$ & 0.812 \\
\hline Malignancy & $3(3.8)$ & $8(6.2)$ & $0.539 *$ \\
\hline Other & $5(6.3)$ & $10(7.8)$ & 0.700 \\
\hline NIMV & $12(15.2)$ & $33(25.6)$ & 0.077 \\
\hline Vasoactive drug & $2(2.5)$ & $7(5.4)$ & $0.488^{*}$ \\
\hline $\begin{array}{l}\text { Body temperature } \\
\left({ }^{\circ} \mathrm{C}, \text { mean } \pm \mathrm{SD}\right)\end{array}$ & $37.27 \pm 1.01$ & $37.41 \pm 1.04$ & 0.352 \\
\hline Bilateral infiltration & $66(83.5)$ & $118(91.5)$ & 0.082 \\
\hline Dyspnea & $61(77.2)$ & $118(91.5)$ & 0.004 \\
\hline $\begin{array}{l}\text { Respiratory rate } \geq 30 \\
\text { (per min) }\end{array}$ & $18(22.8)$ & $108(85.7)$ & $<0.001$ \\
\hline $\mathrm{PaO}_{2} / \mathrm{FiO}_{2}<300$ & $42(53.2)$ & $122(94.6)$ & $<0.001$ \\
\hline $\begin{array}{l}\mathrm{SaO}_{2}<90 \% \text { or } \mathrm{PaO}_{2} \\
<70 \mathrm{mmHg}\end{array}$ & $37(46.8)$ & $122(76.7)$ & $<0.001$ \\
\hline $\begin{array}{l}\text { Hypotension (MAP } \\
<65 \mathrm{mmHg} \text { ) }\end{array}$ & $4(5.1)$ & $16(12.4)$ & 0.081 \\
\hline $\begin{array}{l}\text { Organ dysfunction } \\
\text { signs }\end{array}$ & $14(17.7)$ & $36(27.9)$ & 0.095 \\
\hline $\begin{array}{l}\text { Skin perfusion } \\
\text { disorder }\end{array}$ & $3(3.8)$ & $17(13.2)$ & 0.029 \\
\hline Lactate $\geq 2(\mathrm{mmol} / \mathrm{L})$ & $23(29.1)$ & $58(45.0)$ & 0.023 \\
\hline Lactate $\geq 4(\mathrm{mmol} / \mathrm{L})$ & $15(19.0)$ & $30(23.3)$ & 0.468 \\
\hline \multicolumn{4}{|c|}{$\begin{array}{l}\text { NIMV: Non-invasive mechanical ventilation, } \mathrm{PaO}_{2}: \text { Partial pressure of } \\
\text { oxygen, } \mathrm{FiO}_{2} \text { : Fraction of inspired oxygen, } \mathrm{SaO}_{2}: \text { Arterial blood oxygen } \\
\text { saturation. }{ }^{*} \text { means Fisher's Exact test and }{ }^{\mathrm{a}} \mathrm{means} \geq 5 \mathrm{~L} / \text { min despite } \\
\text { the oxygen therapy ICU: Intensive care unit, } \mathrm{COV} \text { ID-19: Coronavirus } \\
\text { disease-2019, SD: Standard deviation }\end{array}$} \\
\hline
\end{tabular}

Table 2. Comparison of laboratory findings and clinical outcomes in patients with COVID-19

\begin{tabular}{|c|c|c|c|}
\hline Parameters & $\begin{array}{l}\text { Patients non- } \\
\text { admitted to } \\
\text { ICU }(n=79) \\
\text { (mean } \pm \text { SD) } \\
\text { Median (IQR) }\end{array}$ & $\begin{array}{l}\text { Patients admitted } \\
\text { to ICU }(n=129) \\
\text { (mean } \pm \text { SD) } \\
\text { Median (IQR) }\end{array}$ & $p$ \\
\hline $\mathrm{pH}$ & $\begin{array}{l}7.42(7.40- \\
7.43)\end{array}$ & $7.44(7.39-7.46)$ & $0.012^{\star}$ \\
\hline $\mathrm{pCO}_{2}(\mathrm{mmHg})$ & $37(34-41)$ & $36(33-42)$ & $0.106^{*}$ \\
\hline $\mathrm{PO}_{2}(\mathrm{mmHg})$ & $64(61-68)$ & $58(51-66)$ & $0.017^{*}$ \\
\hline $\mathrm{SaO}_{2}(\%)$ & $90(89-92)$ & $88(80-91)$ & $<0.001^{*}$ \\
\hline $\mathrm{HCO}_{3}(\mathrm{mEq} / \mathrm{L})$ & $24.3 \pm 2.5$ & $24.1 \pm 4.1$ & 0.758 \\
\hline Lactate (mmol/L) & $1.49 \pm 0.54$ & $2.14 \pm 1.10$ & 0.151 \\
\hline CRP (mg/L) & $133(61-190)$ & $142(50-252)$ & $0.347^{\star}$ \\
\hline $\begin{array}{l}\text { Procalcitonin (ng/ } \\
\mathrm{mL} \text { ) }\end{array}$ & $\begin{array}{l}0.56(0.35- \\
1.38)\end{array}$ & $0.49(0.26-1.10)$ & $0.196^{\star}$ \\
\hline WBC $\left(10^{9} / \mathrm{L}\right)$ & $8.8(6.6-9.2)$ & $8.4(6.5-10.6)$ & $0.901 *$ \\
\hline $\begin{array}{l}\text { Lymphocyte } \\
\left(10^{9} / \mathrm{L}\right)\end{array}$ & $0.86 \pm 0.32$ & $0.61 \pm 0.20$ & $<0.001$ \\
\hline D-dimer (ng/mL) & $385(297-565)$ & $1654(965-2970)$ & $<0.001 *$ \\
\hline Ferritin $(\mathrm{ng} / \mathrm{mL})$ & $488 \pm 268$ & $801 \pm 473$ & $<0.001$ \\
\hline $\begin{array}{l}\text { Fibrinogen (mg/ } \\
\mathrm{dL} \text { ) }\end{array}$ & $388 \pm 30$ & $435 \pm 132$ & 0.401 \\
\hline $\begin{array}{l}\text { Lactate } \\
\text { dehydrogenase } \\
\text { (U/L) }\end{array}$ & $418(398-494)$ & $398(283-656)$ & $0.447^{\star}$ \\
\hline Troponin (ng/mL) & $10(9.7-18.9)$ & $17.5(9.2-62)$ & $0.527^{\star}$ \\
\hline $\begin{array}{l}\text { Aspartate } \\
\text { transaminase (U/L) }\end{array}$ & $24(23-29)$ & $46(32-59)$ & $0.144^{\star}$ \\
\hline $\begin{array}{l}\text { Alanine } \\
\text { transaminase }(\mathrm{U} / \mathrm{L})\end{array}$ & $21(18-61)$ & $42(24-68)$ & $0.139^{\star}$ \\
\hline $\begin{array}{l}\text { LOS-ICU time } \\
\text { (day) }\end{array}$ & - & $9(4-17)$ & - \\
\hline $\begin{array}{l}\text { LOS-Hospital time } \\
\text { (day) }\end{array}$ & $13(10-15)$ & $16(12-22)$ & $<0.001 *$ \\
\hline \multicolumn{4}{|c|}{$\begin{array}{l}\mathrm{pH} \text { : Potential of hydrogen, } \mathrm{PCO}_{2} \text { : Partial pressure of carbon dioxide, } \mathrm{PO}_{2} \text { : } \\
\text { Partial pressure of oxygen, } \mathrm{SaO}_{2} \text { : Arterial blood oxygen saturation, } \mathrm{HCO}_{3} \text { : } \\
\text { Bicarbonate, CRP: C-reactive protein, WBC: White blood count, LOS-ICU: } \\
\text { Length of stay in the intensive care unit, LOS-Hospital: Length of stay in } \\
\text { the hospital, SD: Standard deviation, ICU: Intensive care unit, COVID-19: } \\
\text { Coronavirus disease-2019, *Mann-Whitney U test }\end{array}$} \\
\hline
\end{tabular}

(OR): 2.687; confidence interval (Cl) 95\%: 1.172-6.164), 2.7 times higher in patients with two comorbid diseases (OR: 2.774, Cl 95\%: 1.212-6.348), 3.1 times higher in patients with three comorbid diseases (OR: 3.174, Cl 95\%: 1.318-7.642), and 9.8 times higher in patients with four or more comorbid diseases (OR: 9.825, Cl 95\%: 2.557-37.749) compared to the patients with no comorbid diseases (Table 3). 
ROC analysis was performed for the ferritin, D-dimer, and lymphocyte counts, which differed significantly between groups in laboratory parameters, in order to determine a cut-off value to predict ICU admission. As a result of the ROC analysis performed for the ferritin value, the cutoff value was determined as $520 \mathrm{ng} / \mathrm{mL}$ according to the Youden $\mathrm{J}$ index [area under curve (AUC): 0.761, $\mathrm{p}<0.00$ ]). It was determined that values above 520 required ICU admission in patients with COVID-19, with $66.9 \%$ sensitivity and $67.9 \%$ specificity (Figure 1). The cut-off value for the D-dimer value was determined as $765 \mathrm{ng} / \mathrm{mL}$ (AUC: 0.947 , $\mathrm{p}<0.001)$. Accordingly, it was found that values above 765

Table 3. Logistic regression of the effect of comorbid disease burden on the admission of patients with COVID-19 to the intensive care unit

\begin{tabular}{llll}
\hline Parameters & OR & Cl 95 & P \\
\hline Comorbidity & \multicolumn{3}{l}{} \\
\hline Non & Reference & \\
\hline 1 & 2.687 & $1.172-6.164$ & 0.020 \\
\hline 2 & 2.774 & $1.212-6.348$ & 0.016 \\
\hline 3 & 3.174 & $1.318-7.642$ & 0.010 \\
\hline$\geq 4$ & 9.825 & $2.557-37.749$ & 0.001 \\
\hline
\end{tabular}

OR: Odds ratio, Cl: Confidence interval, COVID-19: Coronavirus disease-2019

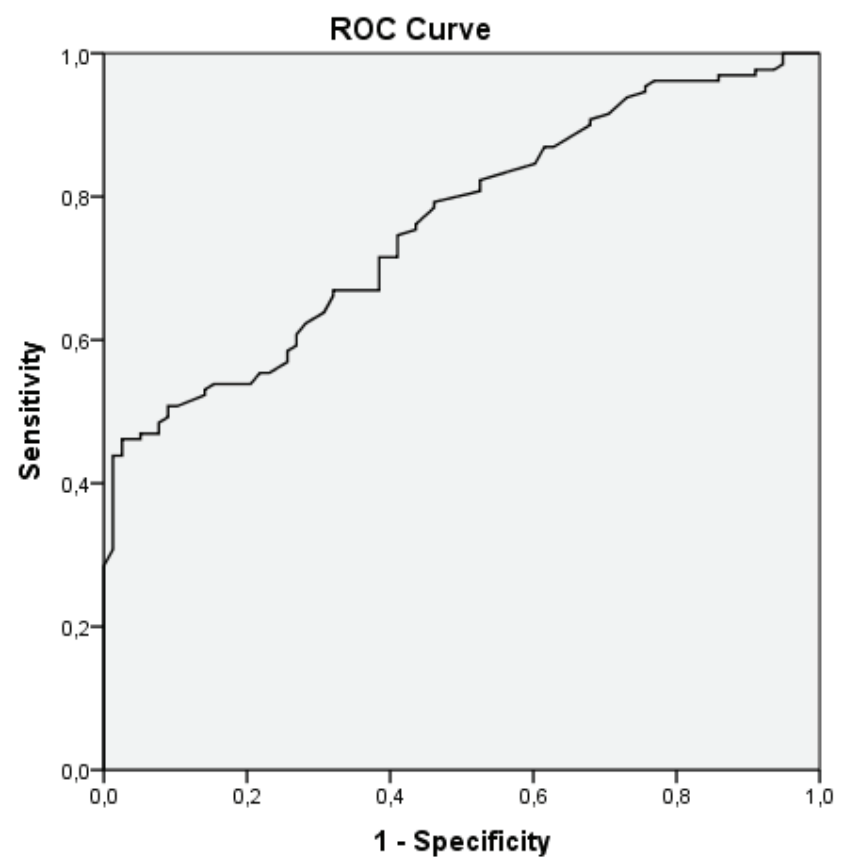

Diagonal segments are produced by ties.

Figure 1. ROC curves for ferritin ROC: Receiver operator characteristic $\mathrm{ng} / \mathrm{mL}$ required ICU admission in patients with COVID-19, with $91.1 \%$ sensitivity and $88.5 \%$ specificity (Figure 2). As a result of the ROC analysis performed for the lymphocyte count, the cut-off value was determined as 0.89 109/L (AUC:

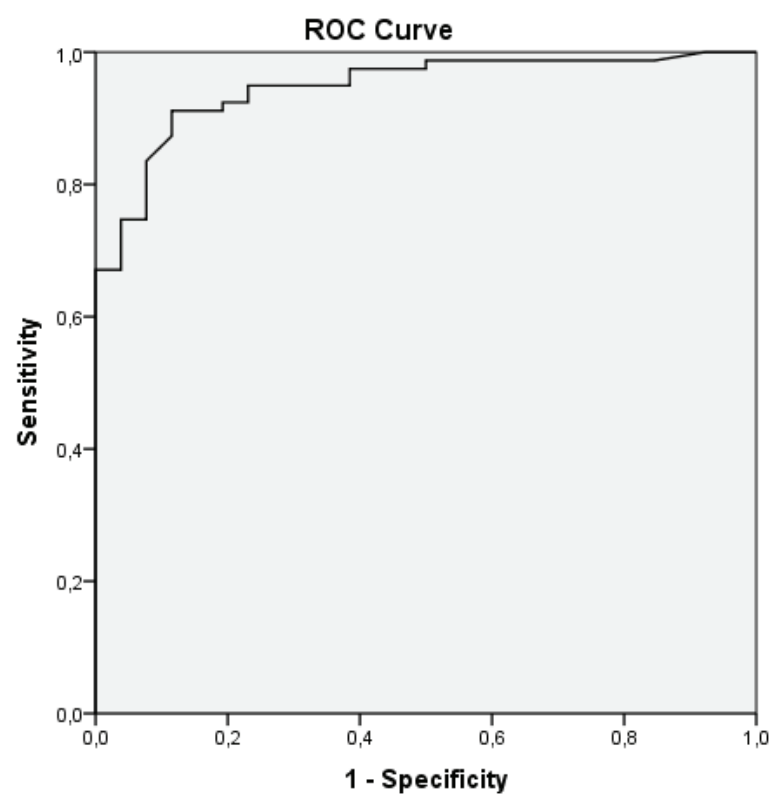

Diagonal segments are produced by ties.

Figure 2. ROC curves for D-dimer

ROC: Receiver operator characteristic

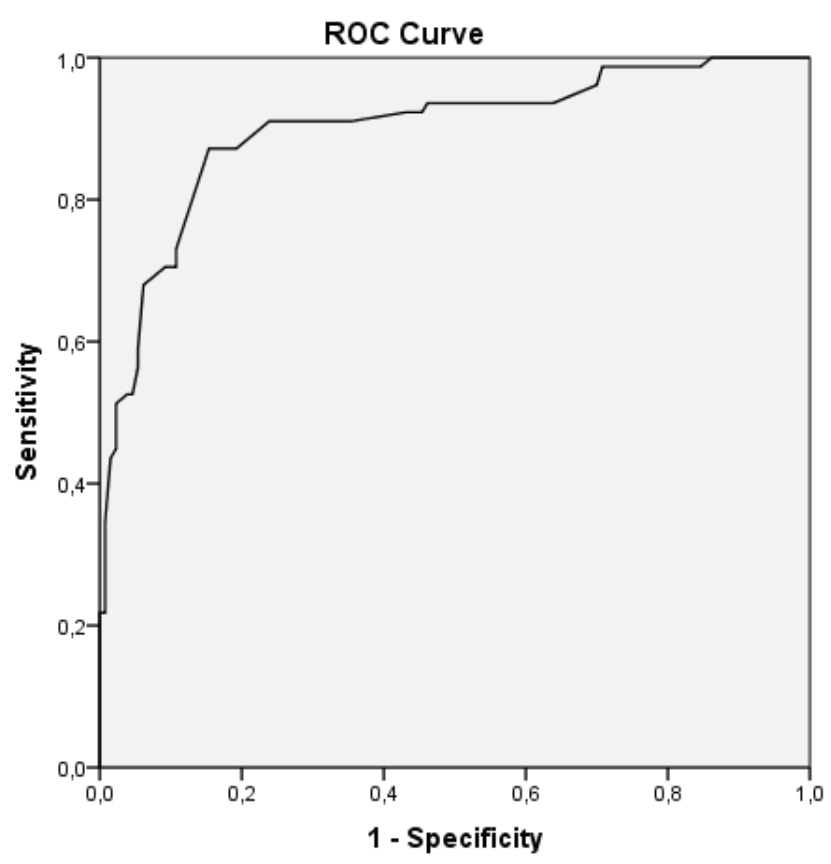

Diagonal segments are produced by ties.

Figure 3. ROC curves for lymphocyte count ROC: Receiver operator characteristic 
$0.899, p<0.001$ ), and the values below $0.89109 / \mathrm{L}$ were found to require ICU admission in patients with COVID-19 (Figure 3), with $87.2 \%$ sensitivity and $84.6 \%$ specificity (Figure 3 ).

Finally, the duration of ICU hospitalization in patients admitted to the ICU was 9 (4-17) days, the need for invasive mechanical ventilation was $72.9 \%$ (94), and the mortality was found to be $55.8 \%(72 / 129)$. The length of hospitalization was higher in the ICU group $(p<0.001)$.

\section{DISCUSSION}

In this study, which was planned to guide the early identification of populations sensitive to the COVID-19 outbreak, it was determined that the rate of critical disease development increased in the male gender at the age of 85 and over. In our study, the need for more IC in patients over the age of 85 was consistent with previous studies. However, contrary to some studies, which indicated an increased need for ICU admission over the age of 65, we were not able to determine an effect of age on the need for ICU in patient groups below the age of 85 (14). In many similar studies, it was determined that the male gender and advanced age had higher severity of disease and higher rates of admission to the ICU $(15,16)$. In a study conducted with 1591 ICU patients in Italy, the prevalence rate of males was $82.0 \%$ (17). This suggests that hospitalized geriatric COVID-19 patients of the male gender may have an increased risk of clinical deterioration that required ICU admission.

Comorbidities, in addition to epidemiological variables, are potentially significant factors that might influence the severity and prognosis of COVID-19. In favor of the results obtained in similar studies reporting that circulatory and endocrine comorbidities are common in COVID-19 patients, it was determined in our study that at least one comorbidity was observed in $79 \%$ of hospitalized patients due to COVID-19 and the presence of comorbidity increased the need for ICU admission (18). In a similar study previously conducted on 5279 patients, it was found that the $80 \%$ of hospitalized patients had at least one comorbidity (16). In our study, the most common comorbidity was determined as hypertension. This finding supports the observations of previous studies that determined hypertension as the most common comorbidity $(6,14,17)$. It is believed that the most common comorbidity, hypertension, is related to the angiotensin converting enzyme receptor, which is an important regulator of blood pressure and also the binding site of SARS-CoV-2 (19). In our study, no relationship was found between hypertension and ICU admission. By contrast, it was determined that the presence of any of the DM, CVD, and COPD increased the risk of critical disease development and ICU hospitalization in patients with COVID-19. In terms of diabetes, a meta-analysis of six studies (1.527 patients) found that the prevalence was twice as high in the IC group compared with the patients with mild COVID-19 (20). Another study showed diabetes to be 3.6 times more common in ICU patients compared to COVID-19 patients who were not admitted to the ICU (21). The worse outcomes of patients with both COVID-19 and diabetes may be attributed to the additional underlying comorbidities associated with diabetes. According to our findings, it was determined that COPD, although it was rarer than other comorbidities, increased the rate of ICU admission. In a similar study, it was found that COPD was an extremely powerful indicator of both disease severity and ICU admission in COVID-19, contributing to the admission of patients with COVID-19 to the ICU as well as invasive ventilation. According to our results, a study conducted for CVD, which was another comorbidity that increased the ICU admission rate, determined that patients with CVD were 3.4 times more likely to be hospitalized in the ICU than patients without any comorbidity (15). In addition, our study determined that multiple comorbidities were associated with higher disease severity of COVID-19. It was found that the probability of ICU admission increased 2.6 times in patients with a single comorbidity compared to the patients without any comorbidity, while this risk increased 9.8 times in the presence of four or more comorbidities. Supporting our findings, previous studies demonstrated that multiple comorbidities were associated with higher disease severity of COVID-19, increasing the probability of ICU hospitalization (18-22). Appropriate triage and careful examination of the medical history will help to identify patients with COVID-19 who are more likely to develop critical disease. In addition, better protection should be provided to patients with COVID-19 and comorbidities following diagnosis.

In the present study, findings of dyspnea, an increased respiratory rate ( $\geq 30$ breaths $/ \mathrm{min}$ ), and hypoxia were more common in patients who were admitted to the ICU. In another study, it was determined that dyspnea increased the need for ICU 6.6 times (21). Considering the importance of dyspnea in predicting admission to the ICU, attention should be paid to early hospitalization, clinical intervention, and close monitoring in patients with dyspnea. It is an expected situation that patients with markers of hypoxemia $\left(\mathrm{SaO}_{2}\right.$ $<90 \%$ or $\mathrm{PaO}_{2}<70 \mathrm{mmHg}, \mathrm{PaO}_{2} / \mathrm{FiO}_{2} 300$ despite oxygen support) have a greater need for IC. It is not surprising that patients who are followed in the ICU have lower $\mathrm{SaO}_{2}$ and $\mathrm{PO}_{2}$ values. In another study, the ratio of $\mathrm{PaO}_{2} / \mathrm{FiO}_{2}$ rates were also found to be lower in patients, who were admitted 
to the ICU (23). In another study, patients with oxygen saturation $<88 \%$ were associated with critical illness, and it was determined that hypoxia was an important marker of severe disease despite oxygen support (16).

Considering the lack of definitive treatment and vaccine despite the recent advances, there is a need for rapid and reliable biomarkers for the early diagnosis of patients with COVID-19 who would require ICU admission. Certain biomarkers have been proposed to determine the severity of the disease (11). In the present study, significant differences were found in the lymphocyte count, D-dimer, and ferritin values among the laboratory parameters that could reflect the severity of COVID-19 during the early period. A lymphocyte count below 0.89 109/L was determined to be predictive of critical disease. Because the targeted invasion of SARS-CoV-2 virus particles destroys the cytoplasmic component of the lymphocyte and causes its death, lymphocytopenia is a notable finding among hematological parameters in critically ill patients with SARSCoV-2 infection (24). Significantly lower lymphocyte counts were found in patients who died from COVID-19 compared with survivors $(11,25,26)$. In a study, it was determined that lymphocytopenia occurred in more than $80 \%$ of critically ill patients (10). Low lymphocyte values can be used in the clinic to diagnose novel coronavirus infections or to predict the clinical course.

COVID-19 infection presents with a coagulopathy problem that increases mortality, which is characterized by predominantly high D-dimer levels (5). Coagulopathy and disseminated intravascular coagulation seem to be linked to a high risk of death. In our study, a D-dimer value over 765 $\mathrm{ng} / \mathrm{mL}$ was found to be associated with ICU admission. In a similar study, D-dimer levels higher than $1 \mathrm{ug} / \mathrm{L}$ were found to be the strongest independent predictor of mortality (26). Ferritin was determined as another parameter related to the severity of the disease. In our study, it was determined that a ferritin level higher than $520 \mathrm{ng} / \mathrm{mL}$ was associated with critical COVID-19 illness that would require ICU admission. In individuals with severe COVID-19, high ferritin levels have been documented due to secondary hemophagocytic lymphohistiocytosis (sHLH) and cytokine storm syndrome. A predictive $\mathrm{H}$-score has been proposed based on body temperature, organomegaly, blood cell cytopenia, lipids, fibrinogen, AST, and ferritin levels to predict the probability of developing secondary HLH (27). As the COVID-19 pandemic intensifies, the need for biomarkers that can identify the progression of this disease to serious and deadly forms will increase. Therefore, clinicians should consider a low lymphocyte count and high D-dimer and serum ferritin levels.

\section{Study Limitations}

Our study has certain limitations in addition to its strengths, such as the administration of the same treatment protocol to all patients and avoiding data loss due to the inclusion of patients who spent the entire disease process in our hospital. First, it lacks dynamic clinical and laboratory data due to its retrospective design. The information was gathered from a database of electronic health records. This precluded the intended level of detail, which could be obtained with manual review of the medical records. All our patients were from a single geographical region, and they were treated in the same health center. Therefore, despite the diversity in our patient population, the factors associated with the results may differ in other geographic regions. Some of the patients in the group who were not admitted to the hospital may have been transferred to another facility. Certain factors, such as secondary infection, that may have an impact on prognosis could not be evaluated. The likelihood of obesity, which contributes to death in patients with COVID-19, was not included in the study due to the lack of data on BMI. In addition, the underreporting of comorbidities that may have arisen from the lack of awareness in patients and/ or the lack of diagnostic tests during the reporting of comorbid diseases, could have caused the overestimation of the relationship with the negative result in terms of its strength.

\section{CONCLUSION}

In conclusion, the male gender, advanced age, and concurrent comorbidities in patients with COVID-19 largely determine the need for ICU admission. In addition, multiple comorbidities are associated with higher severity of COVID-19. Triage, which could be administered by careful review of the patient's medical history, would help to identify patients with comorbidities, who are more likely to develop critical disease. In addition, it is believed that low lymphocyte count, and high D-dimer and ferritin levels may guide clinicians in early and rational triage of patients who require ICU admission.

\section{ETHICS}

Ethics Committee Approval: Ethical approval and institutional permission was obtained from the University of Health Sciences Turkey, Gaziosmanpaşa Training and Research Hospital Ethics Committee (decision number: 134, date: 05/08/2020).

Informed Consent: Consent form was filled out by all participants. 


\section{Authorship Contributions}

Surgical and Medical Practices: M.S.S., F.Ö., O.Ö., Ü.A.T., V.D., Concept: M.S.S., F.Ö., O.Ö., Ü.A.T., V.D., Design: M.S.S., F.Ö., O.Ö., Ü.A.T., V.D., Data Collection or Processing: M.S.S., F.Ö., O.Ö., Ü.A.T., V.D., Analysis or Interpretation: M.S.S., Ü.A.T., Literature Search: M.S.S., F.Ö., O.Ö., Ü.A.T., V.D., Writing: M.S.S., F.Ö., O.Ö., Ü.A.T., V.D.

Conflict of Interest: No conflict of interest was declared by the authors.

Financial Disclosure: The authors declared that this study received no financial support.

\section{REFERENCES}

1. Del Rio C, Malani PN. COVID-19-New Insights on a Rapidly Changing Epidemic. JAMA 2020;323:1339-40.

2. World Health Organization. WHO Director-General's opening remarks at the media briefing on COVID-19-11 March 2020. Available from: https://www.who.int/dg/speeches/detail/whodirector-general-s-opening-remarks-at-the-media-briefing-oncovid-19---11-march-2020 [Last accessed on 2020 April 09].

3. World Health Organization. WHO Rolling updates on coronavirus disease (COVID-19), 2020. Available from: https://www.who.int/ emergencies/diseases/novel-coronavirus-2019 [Last accessed on 2020 April 09].

4. Guan WJ, Ni ZY, Hu Y, Liang WH, Ou CQ, He JX, et al. Clinical Characteristics of Coronavirus Disease 2019 in China. N Engl J Med 2020;382:1708-20.

5. Chen N, Zhou M, Dong $X, Q u$ J, Gong $F$, Han $Y$, et al. Epidemiological and clinical characteristics of 99 cases of 2019 novel coronavirus pneumonia in Wuhan, China: a descriptive study. Lancet 2020;395:507-13.

6. Richardson S, Hirsch JS, Narasimhan M, Crawford JM, McGinn T, Davidson KW, et al. Presenting Characteristics, Comorbidities, and Outcomes Among 5700 Patients Hospitalized With COVID-19 in the New York City Area. JAMA 2020;323:2052-9.

7. Centers for Disease Control and Prevention COVID-19 Response Team. Severe Outcomes Among Patients with Coronavirus Disease 2019 (COVID-19) - United States, February 12-March 16, 2020. Centers for Disease Control and Prevention Morbidity and Mortality Weekly Report (MMWR) 2020;69(12):343-346. doi:10.15585/mmwr. mm6912e2

8. Remuzzi A, Remuzzi G. COVID-19 and Italy: what next? Lancet 2020;395:1225-8.

9. COVID-19 Surveillance Group. Characteristics of COVID-19 patients dying in Italy Report based on available data on March 20th, 2020. Rome, Italy: Instituto Superiore Di Sanita, 2020. Available from: https://www.epicentro.iss.it/coronavirus/bollettino/ Report-COVID-2019_20_marzo_eng.pdf[Last accessed on 2020 April 25].

10. Yang $X, Y u Y, X u J$, Shu $H, X i a ~ J$, Liu $H$, et al. Clinical course and outcomes of critically ill patients with SARS-CoV-2 pneumonia in Wuhan, China: a single-centered, retrospective, observational study. Lancet Respir Med 2020;8:475-81.

11. Velavan TP, Meyer CG. Mild versus severe COVID-19: Laboratory markers. Int J Infect Dis 2020;95:304-7.
12. Republic of Turkey Ministry of Health, Directorate General of Public Health COVID-19 (SARS-CoV-2 Infection) Guide: COVID-19 Adult Patient Management and Treatment. Ankara, Turkey: Republic of Turkey, Ministry of Health; 2020. Available from: https://ohsad. org/wp-content/uploads/2020/03/COVID19__Hasta_Yonetimi_ve_ Tedavisi.pdf [Last accessed on 2020 September 10].

13. Republic of Turkey Ministry of Health, Directorate General of Public Health COVID-19 (SARS-CoV-2 Infection) Guide: Study of Scientific Board (online). Ankara, Turkey: Republic of Turkey, Ministry of Health; 2020. Available from: https://ohsad.org/wp-content/ uploads/2020/04/COVID-19_Rehberi-2.pdf [Last accessed on 2020 September 10].

14. Suleyman G, Fadel RA, Malette KM, Hammond C, Abdulla H, Entz A, et al. Clinical Characteristics and Morbidity Associated With Coronavirus Disease 2019 in a Series of Patients in Metropolitan Detroit. JAMA Netw Open 2020;3:e2012270.

15. Fang $X$, Li S, Yu H, Wang P, Zhang Y, Chen Z, et al. Epidemiological, comorbidity factors with severity and prognosis of COVID-19: a systematic review and meta-analysis. Aging (Albany NY) 2020;12:12493-503.

16. Petrilli CM, Jones SA, Yang J, Rajagopalan H, O'Donnell L, Chernyak Y, et al. Factors associated with hospital admission and critical illness among 5279 people with coronavirus disease 2019 in New York City: prospective cohort study. BMJ 2020;369:m1966.

17. Grasselli G, Zangrillo A, Zanella A, Antonelli M, Cabrini L, Castelli A, et al. Baseline Characteristics and Outcomes of 1591 Patients Infected With SARS-CoV-2 Admitted to ICUs of the Lombardy Region, Italy. JAMA 2020;323:1574-81.

18. Guan WJ, Liang WH, Zhao Y, Liang HR, Chen ZS, Li YM, et al. Comorbidity and its impact on 1590 patients with COVID-19 in China: a nationwide analysis. Eur Respir J 2020;55:2000547.

19. Turner AJ, Hiscox JA, Hooper NM. ACE2: from vasopeptidase to SARS virus receptor. Trends Pharmacol Sci 2004;25:291-4.

20. Li B, Yang J, Zhao F, Zhi L, Wang X, Liu L, et al. Prevalence and impact of cardiovascular metabolic diseases on COVID-19 in China. Clin Res Cardiol 2020;109:531-8.

21. Jain V, Yuan JM. Predictive symptoms and comorbidities for severe COVID-19 and intensive care unit admission: a systematic review and meta-analysis. Int J Public Health 2020;65:533-46.

22. Sabaz MS, Aşar S. Association of Charlson Comorbidity and Pneumonia Severity Indices with Mortality in Patients with Coronavirus Disease-2019 in the Intensive Care Unit. J Turk Soc Intens Care 2021;19:33-41.

23. Wang D, Hu B, Hu C, Zhu F, Liu X, Zhang J, et al. Clinical Characteristics of 138 Hospitalized Patients With 2019 Novel Coronavirus-Infected Pneumonia in Wuhan, China. JAMA 2020;323:1061-9.

24. Gu J, Gong E, Zhang B, Zheng J, Gao Z, Zhong Y, et al. Multiple organ infection and the pathogenesis of SARS. J Exp Med 2005;202:415-24.

25. Erol AT, Aşar S, Sabaz MS, Ören Bilgin B, Çukurova. Risk factors for 28-day mortality among COVID-19 patients in an intensive care unit of a tertiary care center in Istanbul. Med J Bakirkoy 2021;17:100-7.

26. Zhou F, Yu T, Du R, Fan G, Liu Y, Liu Z, et al. Clinical course and risk factors for mortality of adult inpatients with COVID-19 in Wuhan, China: a retrospective cohort study. Lancet 2020;395:1054-62.

27. Mehta P, McAuley DF, Brown M, Sanchez E, Tattersall RS, Manson JJ; HLH Across Speciality Collaboration, UK. COVID-19: consider cytokine storm syndromes and immunosuppression. Lancet 2020;395:1033-4. 